\title{
Komposisi Jenis Alga Makrobentik Divisi Phaeophyta di Zona Intertidal Pantai Pancur Taman Nasional Alas Purwo
}

\author{
(Species Composition of Macrobentic Algae Division Phaeophyta in Interdal Zone \\ Pancur Beach Alas Purwo National Park)
}

\author{
Deris Erlita Kumalasari, Hari Sulistiyowati, Dwi Setyati \\ Jurusan Biologi, Fakultas Matematika dan Ilmu Pengetahuan Alam, Universitas Jember (UNEJ) \\ Jln. Kalimantan 37, Jember 68121 \\ E-mail: deriserlita12@yahoo.com
}

\begin{abstract}
Abstrak
Phaeophyta merupakan salah satu kelompok makroalga yang tersebar melimpah di zona intertidal. Alga makrobentik ini memiliki struktur talus yang terdiri atas bagian holdfast, stipe, dan blade. Kelompok tersebut memiliki kandungan warna yang disebut pigmen fukosantin. Metode yang digunakan adalah road sampling dengan melakukan penyusuran seluruh area sampling menggunakan GPS (Global Positioning System). Jenis-jenis alga yang ditemukan diidentifikasi dan dideskripsikan secara morfologi. Analisis komposisi jenis dilakukan secara deskripsi kualitatif . Hasil yang diperoleh yaitu terdapat empat jenis Phaeophyta yang terdiri atas Sargassum sp., Padina australis, Spatoglossum sp., dan Turbinaria ornata. Jenis-jenis yang ditemukan umumnya memiliki karakteristik morfologi holdfastnya bentuk cakram dan lempeng, stipe pendek, serta blade berupa lembaran dan silindris.
\end{abstract}

Kata Kunci: Pantai Pancur, Phaeophyta, Struktur Morfologi, Zona intertidal

\begin{abstract}
Phaeophyta is one group of macroalgae that widely spread in the intertidal zone. Macrobentic algae thallus has a structure consisting holdfast, stipe and blade. The group contains pigment color called fukosantin. The method of this research is road sampling, which is walktrough the sampling area using GPS (Global Positioning System). The species of algae that found are identified and described by morphology. Composition analysis is conducted by qualitative description. The results

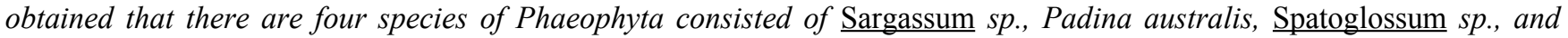
Turbinaria ornata. Generally, the species that found has a holdfast morphological characteristics shape: discs and plates, short stipe, as well as a sheet and cylindrical blade.
\end{abstract}

Keywords: Morphological Structure, Intertidal Zone, Pancur beach, Phaeophyta

\section{PENDAHULUAN}

Alga makrobentik merupakan kelompok organisme talus yang mirip tumbuhan. Jenis ini memiliki keanekaragaman yang melimpah dan tersebar di sepanjang zona intertidal. Organisme yang tergolong kelompok protista ini memiliki fungsi ekologis dan biologis dalam komunitasnya. Fungsi ekologis tersebut yaitu sebagai tempat pemijahan, untuk berlindung berbagai jenis ikan kecil, dan tempat mencari makanan bagi hewan herbivor. Peran biologis organisme ini yaitu sebagai penghasil bahan organik dari proses fotosintesis untuk kelangsungan hidup organisme sekitarnya [2]. Jenis tersebut juga memiliki potensi ekonomis yaitu dimanfaatkan sebagai bahan makanan, pembuatan produk karet, kertas, cat, kosmetik, dan obat seperti obat pencahar [3]. Salah satu makroalga yang memiliki fungsi di atas adalah alga coklat makrobentik.

Alga coklat makrobentik ditemukan di perairan pantai Indonesia dengan keanekaragamannya yang tinggi [9]. Kelompok organisme tersebut memiliki karateristik warna bervariasi yang disebabkan oleh adanya pigmen penyusunnya. Pigmen fukosantin pada Phaeophyta memberikan gradasi warna berbeda pada setiap jenis, yaitu berwarna coklat gelap ataupun coklat kekuningan [3]. Struktur talus pada alga coklat makrobentik sendiri ada 3 bagian yaitu blade, holdfast, dan stipe. Blade adalah bagian daun yang berbentuk pipih dari tallus. Holdfast adalah bagian dari talus berada di bawah yang berfungsi sebagai struktur yang melekat pada substrat. Stipe adalah struktur yang mendukung blade [3]. Kelompok ini sebagian besar ditemukan di zona intertidal.

Zona intertidal adalah zona yang terdapat pada daerah pasang surut air laut. Menurut [2] alga coklat makrobentik ditemukan predominan di zona ini. Penelitian tentang keberadaan alga coklat makrobentik telah dilakukan oleh [4] di Pantai Pancur Taman Nasional Alas Purwo dengan ditemukannya tiga jenis alga coklat makrobentik di zona intertidal. Lima tahun berikutnya belum ada lagi penelitian tentang alga coklat sehingga belum diketahui adanya perubahan komposisi jenis divisi Phaeophyta di zona intertidal. Penelitian kembali perlu dilakukan untuk mengetahui perubahan jenis alga coklat makrobentik.

\section{METODE PENELITIAN}

Penelitian dilakukan pada bulan Mei sampai Juni 2016 di zona intertidal Pantai Pancur, Taman Nasional Alas 
Purwo. Sampling dilakukan pada surut maksimal disepanjang $1,7 \mathrm{~km}$ panjang pantai dengan titik koordinat $8^{\circ} 40^{\prime} 54^{\prime \prime} \mathrm{LS}-114^{\circ} 22^{\prime} 32^{\prime \prime} \mathrm{BT} \quad$ sampai $8^{\circ} 41^{\prime} 06^{\prime \prime} \mathrm{LS}-$ $114^{\circ} 22^{\prime} 42^{\prime \prime}$ BT.

Pengambilan data alga makrobentik dilakukan dengan metode jelajah (road sampling) yang dimulai dari tubir menuju pantai. Semua jenis yang ditemukan di identifikasi dan di deskripsikan secara morfologi untuk bagian holdfast, stipe, dan blade. Identifikasi spesimen dilakukan di Laboratorium Ekologi Jurusan Biologi Fakultas Matematika dan Ilmu Pengetahuan Alam Universitas Jember. Hasil deskripsi akan diverifikasi di Laboratorium Pusat Penelitian Oseanografi (P2O) LIPI Jakarta.

Phaeophyta yang ditemukan dianalisis secara kualitatif berdasarkan takson mulai dari kelas, bangsa, suku, marga dan jenis dilengkapi dengan karakter morfologinya.

\section{HASIL PENELITIAN}

Komposisi alga makrobentik divisi Phaeophyta di Pantai Pancur terdiri atas satu kelas, dua bangsa, dua suku, empat marga dan empat jenis (Tabel 1)

Tabel 1. Komposisi jenis alga coklat makrobentik di Pantai Pancur

\begin{tabular}{|c|c|c|c|c|}
\hline Kelas & Bangsa & Suku & Marga & Jenis \\
\hline \multirow[t]{4}{*}{$\begin{array}{l}\text { Phaeop } \\
\text { hyceae }\end{array}$} & Fucales & $\begin{array}{l}\text { Sargassa } \\
\text { ceae }\end{array}$ & $\begin{array}{l}\text { Sargas } \\
\text { sum }\end{array}$ & Sargassum sp. \\
\hline & & & $\begin{array}{l}\text { Turbin } \\
\text { aria }\end{array}$ & $\begin{array}{l}\text { Turbinaria ornata } \\
\text { Agardh, J.G }\end{array}$ \\
\hline & $\begin{array}{l}\text { Dictyotal } \\
\text { es }\end{array}$ & $\begin{array}{l}\text { Dictyota } \\
\text { ceae }\end{array}$ & $\begin{array}{l}\text { Spatog } \\
\text { lossum }\end{array}$ & Spatoglossum sp. \\
\hline & & & Padina & $\begin{array}{l}\text { Padina australis } \\
\text { Hauck, F }\end{array}$ \\
\hline
\end{tabular}

Berdasarkan penelitian sebelumnya oleh [4] di Pantai Pancur hanya ditemukan tiga jenis alga coklat makrobentik yang terdiri atas Sargassum sp., P. australis dan Dictyota bartayresiana. Jenis Turbinaria ornata (gambar 4) dan Spatoglossum sp. (Gambar 2), tidak ditemukan pada penelitian tersebut. Perbedaan kemunculan jenis ini dapat disebabkan oleh faktor lingkungan. Kondisi perairan yang baik juga mempengaruhi komposisi jenis yang muncul pada lokasi intertidal di wilayah tersebut.

Suku Sargassaceae terdiri atas dua jenis yaitu Sargassum sp. dan Turbinaria ornata. Kelompok jenis tersebut memiliki holdfast berbentuk cakram. Struktur tersebut berfungsi untuk melekat kuat pada habitat berbatu serta dapat mempertahankan diri di perairan yang berarus sedang [8][6]. Pernyataan tersebut sesuai dengan kondisi di zona intertidal Pantai Pancur yang bersubstrat batuan vulkanik. Habitat yang mendukung serta kondisi perairan yang jernih merupakan faktor penting untuk pertumbuhan alga coklat makrobentik.

Pertumbuhan Phaeophyta juga dipengaruhi oleh musim. Hal ini ditunjukkan oleh suku Sargassaceae (Sargassum dan Turbinaria) (Gambar 1) pada saat musim reproduktif menghasilkan individu baru yang melimpah di wilayah intertidal sebaliknya pada musim tertentu tidak ditemukan di wilayah tersebut [7]. Hasil penelitian menunjukkan jenis dari Sargassum sp. ditemukan melimpah di Pantai Pancur pada substrat berbatu. Hal ini karena batu-batuan mampu melindungi Sargassum dari hempasan laut selatan yang sangat kuat.

Suku lainnya yang ditemukan di Pantai Pancur adalah Dictyotaceae terdiri atas Spatoglossum sp. dan Padina australis (Gambar 3). Menurut [5] jenis tersebut hidup pada habitat dengan substrat pasir, batu berpasir dan terumbu karang.

Karakteristik jenis alga makrobentik yang tergolong divisi Phaeophyta secara umum terdiri atas holdfast yang berbentuk cakram dan lempeng, stipe pendek, serta blade yang berupa lembaran dan silindris. Adapun deskripsi masing-masing jenis yang ditemukan adalah sebagai berikut:

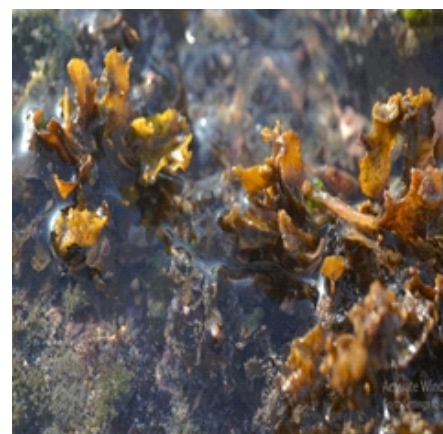

(a)

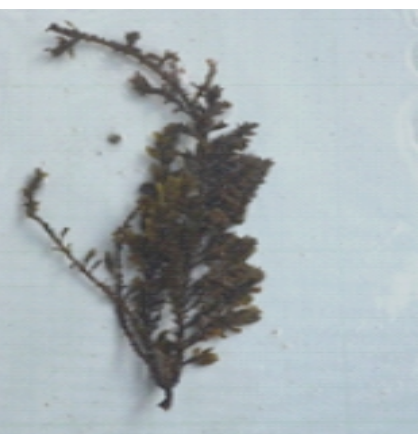

(b)
Gambar 1. (a).Substrat dari Sargassum sp.; (b) Sargassum sp.

Sargassum sp. memiliki bentuk talus silindris dengan cabang yang rimbun. Panjang rata-rata $9 \mathrm{~cm}$. Gelembung gas yang menempel pada blade berfungsi untuk mengapung di perairan. Talus berwarna coklat kekuningan sampai coklat tua. Blade berbentuk lonjong. Stipe menyerupai batang berbentuk silindris. Holdfast berbentuk cakram. Jenis ini ditemukan tumbuh melekat pada substrat berbatu.

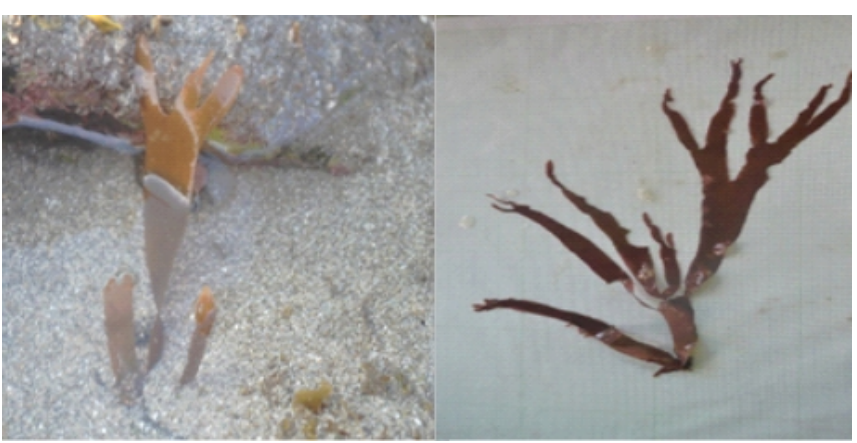

(a)

(b)

Gambar 2. (a) Substrat dari Spatoglossum sp.; (b) Spatoglossum sp.

Talus berbentuk lembaran tipis berwarna coklat tua. Panjang rata-rata $19 \mathrm{~cm}$. Permukaan blade halus dengan tepi rata. Blade berbentuk lancet dan bercabang pada ujungnya. Stipe tidak terliihat jelas sesampai struktur talus hanya terdiri atas blade dan holdfast. Holdfast berbentuk lempengan digunakan untuk melekat pada substrat pasir. 


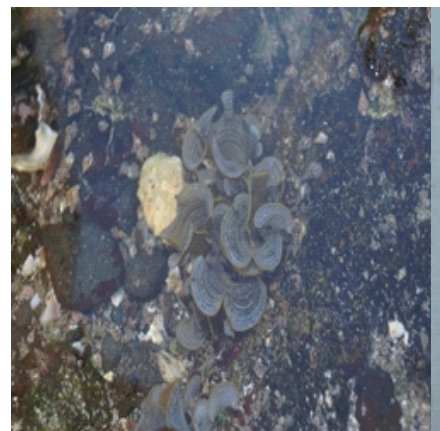

(a)

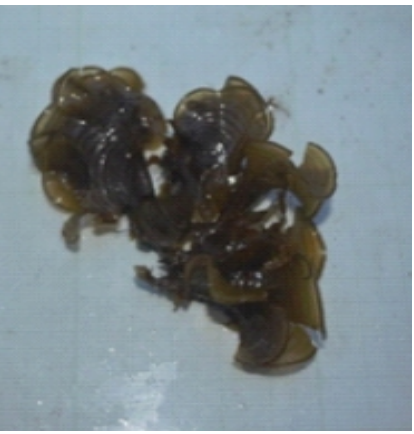

(b)
Gambar 3. (a) Substrat dari Padina australis Hauck, F.; (b) Padina australis Hauck, F

Talus berwarna coklat kekuningan dan berbentuk lembaran tipis yang menyerupai kipas. Panjang rata-rata 7 $\mathrm{cm}$. Bagian ujung blade tipis melebar dan membentuk lobus. Lobus bersegmen-segmen dengan garis-garis melingkar berwarna putih. Stipe tidak terliihat jelas sesampai struktur talus hanya terdiri atas blade dan holdfast. Holdfast berbentuk lempengan. Tumbuh pada substrat batu pasir.

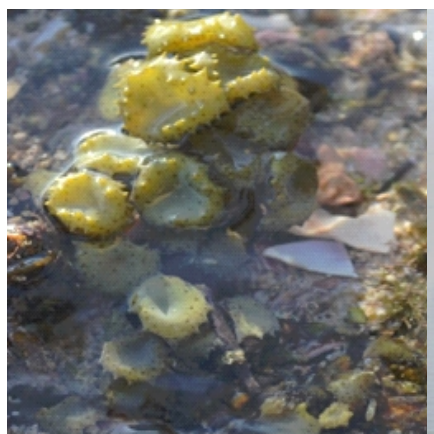

(a)

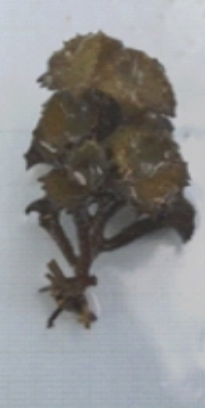

(b)
Gambar 4. (a) Substrat dari Turbinaria ornata Agardh, J.G.; (b) Turbinaria ornata Agardh, J.G

Talus berwarna coklat kekuningan sampai coklat tua. Panjang antara 5-7 cm. Jenis ini memiliki blade yang tebal dan berbentuk seperti corong. Bagian ujung blade membentuk bibir dengan bagian tengah melengkung kedalam. Bagian tepi blade bergerigi. Stipe berupa cabang yang bergabung dengan struktur blade. Holdfast berbentuk cakram. Ditemukan pada substrat berbatu.

\section{KESIMPULAN}

Komposisi jenis alga makrobentik divisi Phaeophyta di zona intertidal Pantai Pancur ditemukan terdiri atas satu kelas, dua bangsa, dua suku, empat marga, dan empat jenis. Keempat jenis tersebut yaitu Sargassum sp., Padina australis, Turbinaria ornata, dan Spatoglossum sp. Karakteristik yang ditemukan yaitu holdfast bentuk cakram dan lempeng, stipe pendek, blade berupa lembaran dan silindris.

\section{UCAPAN TERIMAKASIH}

Terimakasih kepada Laboratorium Pusat Penelitian Oseanografi (P2O) LIPI Jakarta, Laboratorium Ekologi Jurusan Biologi FMIPA Universitas Jember dan Balai Taman Nasional Alas Purwo.

\section{DAFTAR PUSTAKA}

[1] Atmadja, W. S. 1996. Pengenalan Jenis-Jenis Rumput Laut Indonesia:Pengenalan Jenis Algae Coklat (Phaeophyta). Jakarta: Puslitbang Oseanologi LIPI.

[2] Bold, H. C dan M. J. Wynne. 1985. Introduction of the Algae Structure and Reprodduction Second Edition. New Jersey: Prentice-Hall, Inc Englewood Cliffs.

[3] Castro, P dan Huber, M.E. 2003. Marine Biology: fourth edition. New York: MacGraw-Hill Companies.

[4] Farhan, M. 2011. Struktur Komunitas Alga Laut Makrobentik Divisi Phaeophyta di Zona Intertidal Pantai Pancur Taman Nasional Alas Purwo. Skripsi. Tidak Dipublikasikan. Jember: Universitas Jember Press.

[5] Kadi, A. 1988. Rumput Laut (Alga), Jenis, Reproduksi, Produksi, Budidaya dan Pasca Panen. Jakarta: Puslitbang Oeanologi-LIPI.

[6] Kadi, A. 2005. Beberapa Catatan Kehadiran Marga Sargassum di Perairan Indonesia. Jakarta: Pusat Penelitian Oseanografi-LIPI.

[7] Odum, E. P. 1993. Dasar-Dasar Ekologi. Edisi Ketiga. Terjemahan oleh Samingan. T. Yogyakarta: Gajah Mada University Press.

[8] Papalia, S. 2015. Struktur Komunitas Makro Alga Pesisir Pulau Haruku, Kabupaten Maluku Tengah. Jurnal Ilmu dan Teknologi Kelautan Tropis. 7(1): 129142.

[9] Rasyid, A. 2010. Ekstraksi Natrium Alginat dari Alga Coklat Sargassum echinocarphum. Jakarta: Pusat Penelitian Oseanografi -LIPI. 